ourselves can testify, forms a thoroughly comfortable and secure bed or lounge. Mr. Stanley, we believe, was so favourably impressed with the hammock, that he has taken a supply with him in his present exploration; and for explorers in tropical countries, we should think it would prove useful in many ways, as it can not only be used as a bed, but, mounted on a pole, as a travelling litter or palanquin. For those of our readers engaged in explorations of any kind, geological, geographical, botanical, zoological, or even in doing an ordinary tour, in remote districts, we

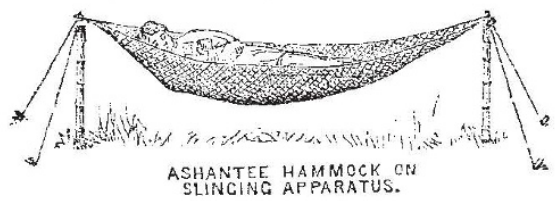

believe the hammock would be found of real service, as it would make them quite independent of sleeping accommodation, and would not increase the weight of their impedimenta by very many ounces. An idea of its construction and its adaptability to almost any circumstances may be obtained from the illustrations we give. We can honestly recommend the hammock as likely to answer all the purposes for which it has been designed.

\section{THE SANITARY INSTITUTE}

THE lecture by Dr. Richardson, published in our issue of last week, has called public attention to the Sanitary Institute of Great Dritain, before which the lecture was delivered. The Institute was founded in July, 1876 , at a public meeting heid at St. James's Hall, and presided over by his Grace the Duke of Northumberland. The Institute has for its work a wide range of subjects. It has sprung, we may say, out of the necessities of the time, and in the first instance may be considered as a nucleus round which will cluster the many men of science who are now employed in carrying out the executive sanitary or health work of the kingdom. The various medical officers of health, the certifying surgeons under the Factory Acts, the engineers and sanitary surveyors of different localities, the mayors of municipalities, and the chairmen and presidents of local boards, all of these must needs take an interest in and in time form the body corporate of an institution framed for the purpose of becoming as it were a voluntary health parliament. In addition to these sections of the Institute there are many other sections of the community which will, we should think, earnestly join in the work. For reasons plainly stated by Dr. Richardson ladies are invited to take part in the proceedings and to help forward sanitary progress. We feel sure there will also be a large class of active men unconnected professionally with sanitary work who will be ambitious to take a part in the great practical scientific labour of the time, the only labour we may say in which science lends herself immediately to the aid and comfort of domestic life and felicity.

The detailed work of the Sanitary Institute has been in some measure projected by its founders; but it is more than probable that in the course of its natural development it will grow into something different from that which is now supposed. At the same time we are bound to say that the plan is sufficiently simple and practical to warrant the expectations of those who have mapped it out. The objects we have seen proposed are all directed to some useful and desirable end. To obtain a registration of the diseases of the kingdom; to establish communications with medical officers of health; to form local branches of the Institute throughout the kingdom; to examine and grant certificates of qualification to local surveyors and inspectors of nuisances, and to form a register of such certificated officers; to investigate the chemical aspects of the sewage question to establish a sanitary exhibition, and to form a library of books on health subjects; - these objects, some of which must needs become a part of every sanitary organisation, are sufficiently comprehensive to cover any amount of work, and to tax any amount of industry that may be found in the best organised public body. So far the prospects of the Institute are brought beyond what is common to such undertakings in their carliest days. Mcmbers are daily being added, and an effective Council has been elected. Already one of the provincial towns, Scarborough, has invited the Institute to hold its first provincial Congress there, and in France a kindred society has been formed in sequence, and, it may be said without offence, in imitation of the one already founded in London. The visit of Dr. De Pietra Santa, of Marié Davy, and other savants from Paris to the meeting on Thursday last, is a significant sign of the good feeling with which the two rival societies have commenced their labours.

For our parts we welcome heartily both Institutes, and shall enjoy the privilege of watching their onward progress and recording their success.

\section{ON THE SOURCE OF THE CARBON OF PLANTS}

EARLY half the dry substance of plants is carbon; and it is conclusively established that they derive, at any rate, the greater part of it, directly from the carbondioxicle of the atmosphere, which the chlorophyll cells have the power of decomposing in sunlight, at the same time evolving oxygen. But this function of vegetation, which is so essential a complement to the processes of animal life, gives rise to many problens hitberto unsolved; and an important one is whether or not plarits avail themselves of other obviously possible sources of carbon than that existing in such very small proportion, although in large actual amount, in the ambiant air.

Our knowledge bearing upon the subject as it exists in the present day, is the resultant of careful investigations by many observers. In the last century Bonnet discovered the gaseous exhalation; Priestley that the gas is oxygen; Ingenhouz that the oxygen is only evolved in sunlight; Sennebier that it is due to the decomposition of carbondioxide, but he believed that the carbon-dioxide is taken up in solution in water. Early in this century de Saussure carried out a long series of experiments on the relations between the carbon-dioxide decomposed, and the oxygen evolved, and on the amount of carbon-dioxide in the air compatible with the healthy development of plants. Since his time many eminent names have been added to the list of patient labourers in this field of inquiry.

Boussingault worked on the question whether the carbon dioxide is absorbed by the leaves, or taken up by water through the roots; and by direct experiments proved that the leaves of plants do take up the carbondioxide, which is so sparingly, though so uniformly, diffused in the atmosphere. His researches led him to conclude that, by far the greater part, if not the whole, of the carbon which enters into the constitution of the organs of plants is derived from atmospheric carbondioxide; "and while drawing attention to the fact that, for healthy and vigorous action, plants require large volumes of air to pass over them, and to the surprising rapidity with which they absorb the carbon-dioxide from it, he makes calculations as to the surface presented to the air by the leaves of different crops. 'Taking the average number of plants growing per hectare (about $2 \frac{1}{2}$ English acres), he estimates that:-

Artichoke gives a surface of 142,410 square metres.

$\begin{array}{lllll}\text { Beetroot ", ", } & 49,921 & \text { ", } \\ \text { Potato ", } & 39,64 I & \text { ", } & \text { ", } \\ \text { Wheat } & 35,490 & \text { ", } & \text {," }\end{array}$

Boussingault also made experiments in regard to the 